\title{
Nutrient and heavy metal composition in select biotic and abiotic components of Varthur wetlands, Bangalore, India
}

\author{
T. V. Ramachandra ${ }^{1,2,3}$ (1) $\cdot$ P. Sudarshan ${ }^{1} \cdot$ S. Vinay $^{1} \cdot$ K. S. Asulabha ${ }^{1} \cdot$ Sincy Varghese ${ }^{1}$
}

Received: 20 March 2020 / Accepted: 20 July 2020 / Published online: 29 July 2020

(c) Springer Nature Switzerland AG 2020

\begin{abstract}
Lakes or wetlands in urban landscapes provide services such as groundwater recharge, provide fish, fodder and food to the dependent local population, mitigate floods, habitat for fauna, support recreation, etc. Unplanned rapid urbanization with globalization and industrialization has led to the sustained inflow of untreated wastewater from domestic and industrial sectors to water bodies leading to eutrophication and heavy metal contamination. This necessities treatment of sewage and industrial effluents, which needs to be technically feasible and economically viable. This communication investigates the distribution and accumulation of nutrients (carbon and nitrogen) and six heavy metals (cadmium, chromium, copper, nickel, lead and zinc) in the sediment and macrophyte samples of Varthur lake, Bangalore. Higher carbon and nitrogen values in sediment samples of the northwest and northeast shorelines were observed, whereas lower carbon and nitrogen values were observed in the samples of middle and outlets of the lake. Shoots of Colocasia esculenta and Alternanthera philoxeroides accumulated higher amount of carbon and nitrogen. Sediment samples of north shoreline and inlet portion of the Lake had high concentration of heavy metals in Alternanthera philoxeroides and Eichhornia crassipes accumulated heavy metals in higher extent among macrophyte species. Sediment samples had higher concentrations of copper ( $\mathrm{Cu}$ ) followed by zinc $(\mathrm{Zn})$, chromium $(\mathrm{Cr})$, lead $(\mathrm{Pb})$, nickel $(\mathrm{Ni})$ and cadmium $(\mathrm{Cd})$. Compared to this, accumulation of heavy metals in macrophyte samples is in the order $\mathrm{Cu}>\mathrm{Zn}>\mathrm{Cr}>\mathrm{Pb}>\mathrm{Ni}>\mathrm{Cd}$. Assessment of bioconcentration factor and translocation factor of metals in macrophytes revealed the prospects of select macrophytes in phytoremediation for mitigating metal pollution through phytoextraction and phytostabilization.
\end{abstract}

Keywords Heavy metal $\cdot$ Sediment $\cdot$ Macrophytes $\cdot$ Phytoremediation $\cdot$ Bangalore $\cdot$ Varthur lake

\section{Introduction}

Wetlands being the transition zone of land and water plays a significant role in nutrient cycling, treatment of water, attenuation of floods, maintaining stream flow, recharge ground water, moderate local microclimate, provision goods (fish, fodder, fuel, drinking water, etc.) and services (regulating, cultural, etc.) to the dependent population [1]. Sustained discharge of untreated or partially treated sewage has been altering the chemical integrity of aquatic environment by enriching the system with nutrients, leading to the eutrophication of urban water bodies [2]. Wastewater generated in the domestic and industrial sectors consists of chemical ions, nutrients and heavy metals [3-6].

Lakebed provides a platform for sediment deposition, which traps heavy metals [7], aiding in the remediation as well as regulating the biological processes. Sediments act as sink of nutrients [8], and analyses of sediments would reveal extent and history of eutrophication. The nutrient

$\checkmark$ T. V. Ramachandra, tvr@iisc.ac.in, http://ces.iisc.ernet.in/energy | ${ }^{1}$ Energy \& Wetlands Research Group, Centre for Ecological Sciences (CES), Indian Institute of Science, Bangalore, Karnataka, India. ${ }^{2}$ Centre for Sustainable Technologies (astra), Indian Institute of Science, Bangalore, Karnataka, India. ${ }^{3}$ Centre for infrastructure, Sustainable Transportation and Urban Planning (CiSTUP), Indian Institute of Science, Bangalore, Karnataka, India. 
budget, ecology, trophic status and rate of evolution of lakes are influenced by plant detritus and sediments. The particulate detritus of plants are the primary source of organic matter, and total organic carbon and small volume is contributed by animal and other sources [9]. Sediment-water interactions are important because of higher sediment surface per volume of water in shallow lakes [10].

Plant communities (macrophytes) in wetlands [11] act as nutrient sink by uptake of elements released by sediment to water column, which will influence water chemistry. Assessment of the chemical composition in the macrophytes provides an information about the uptake ability of plants to nutrients [12], nutrients availability for metabolism and the nutrient value of the plants [13]. The ability of macrophytes to uptake nutrients and metals from soil and water forms the basis of phytoremediation [14]. Nutrient composition or accumulation in the tissues is an important feature for identifying the ecological strategy of the plant species, and this aids in predicting the competitive complex interactions among the plant communities [15, 16] and aboveground biomass stores higher proportion of nutrients [17]. Phytoremediation capability of aquatic macrophytes has been studied earlier by researchers [18-27], and hence, they are being used in monitoring the status of an ecosystem (biomonitoring).

Heavy metals have increased enormously in the environment from anthropogenic sources due to industrialization and enhanced agricultural activities (pesticides, etc.). Heavy metals in the environment have been posing challenges due to the hazardous properties such as toxicity, persistence, accumulation in the biological organism leading to biomagnification in food webs [28-33], which further get transformed into more toxic compounds [34] posing serious challenges to biotic health. The occurrence of toxic pollutants in water bodies (lakes, ponds, streams and rivers) would affect the health of population who depend on these water sources to meet their daily requirements (water, fish, food, etc.). Consumption of water and wetland goods laded with metals would lead to the accumulation in the kidneys, liver and bones of humans, resulting in chronic disruption of metabolic activities, and lead to cardiovascular, neurological and renal diseases $[35,36]$. Table 1 provides the sources and toxic effects of heavy metals on plants and humans. Bottom sediments, plants and other organisms in polluted wetlands contain heavy metals [37] due to bioaccumulation. Analyses of spatial distribution of heavy metals in sediments and macrophytes of wetlands aid in tracing the sources and the extent of contamination, which is useful in remediation and prudent management of water bodies.

Wetlands are distributed across various topographic and climatic regimes and support diverse and unique habitats in India [53]. Due to inadequate management, many of the wetlands in urban and rural areas are subject to anthropogenic pressures, including pollution from industry and households, land use changes in the catchment, tourism, encroachments and over exploitation of their natural resources [53]. Bangalore is located at an altitude of $920 \mathrm{~m}$ above mean sea level, delineating three watersheds, viz. Hebbal, Koramangala-Challaghatta and Vrishabhavathi watersheds (Fig. 1). The undulating terrain in the region has facilitated creation of a large number of tanks for the traditional uses of irrigation, drinking, fishing and washing.

Bangalore, being a part of peninsular India, had the tradition of harvesting water through surface water bodies to meet the domestic water requirements in a decentralized way. After independence, the source of water for domestic and industrial purpose in Bangalore is mainly from the Cauvery River and ground water. Untreated sewage is let into the storm water drains, which progressively converge at the water bodies. Varthur lake is the second largest lake in Bangalore. It is a part of a system of interconnected tanks and canals, i.e., three chain of lakes in the upstream joins Bellandur lake with a catchment area of about $149 \mathrm{~km}^{2}$ (14,979 Hectares), and overflow of this lake gets into Varthur lake and from where it flows down the plateau and joins Pinakini river basin [54]. Thus, Varthur lake receives all the surface runoff, wastewater and sewage from the Bangalore South taluk (about $40 \%$ of Bangalore city sewage). Sustained inflow of untreated sewage and effluents (from industries) has contaminated the lake resulting in eutrophication [55] as the inflow of pollutants has surpassed the lake's assimilative capacity. This has led to algal bloom with extensive growth and spread of invasive macrophytes, resulting in malodor decline of dissolved oxygen [55]. Hence, the current research investigates the level of nutrients (carbon and nitrogen) and predominant heavy metals [cadmium (Cd), chromium (Cr), copper ( $\mathrm{Cu})$, nickel (Ni), lead (Pb) and zinc ( $\mathrm{Zn})$ ] concentrations in the Varthur lake through analysis of representative sediment and macrophyte samples.

\section{Materials and methods}

\subsection{Study area}

Varthur Lake located at $12.9407^{\circ}$ to $12.9566^{\circ} \mathrm{N}$ and $77.67189^{\circ}$ to $77.7476^{\circ} \mathrm{E}$ is the second largest lake in the Bangalore city (BBMP) (Fig. 1). It is situated at Varthur ward in Bangalore east with an area of 180.8 ha (447 acres 14 guntas) and spread across Ammanikere and Bellandur Khane villages. The catchment of Varthur lake is around $279 \mathrm{~km}^{2}$ with 96 cascaded lakes. Land use analyses study using temporal (1970-2016) remote sensing data showed 


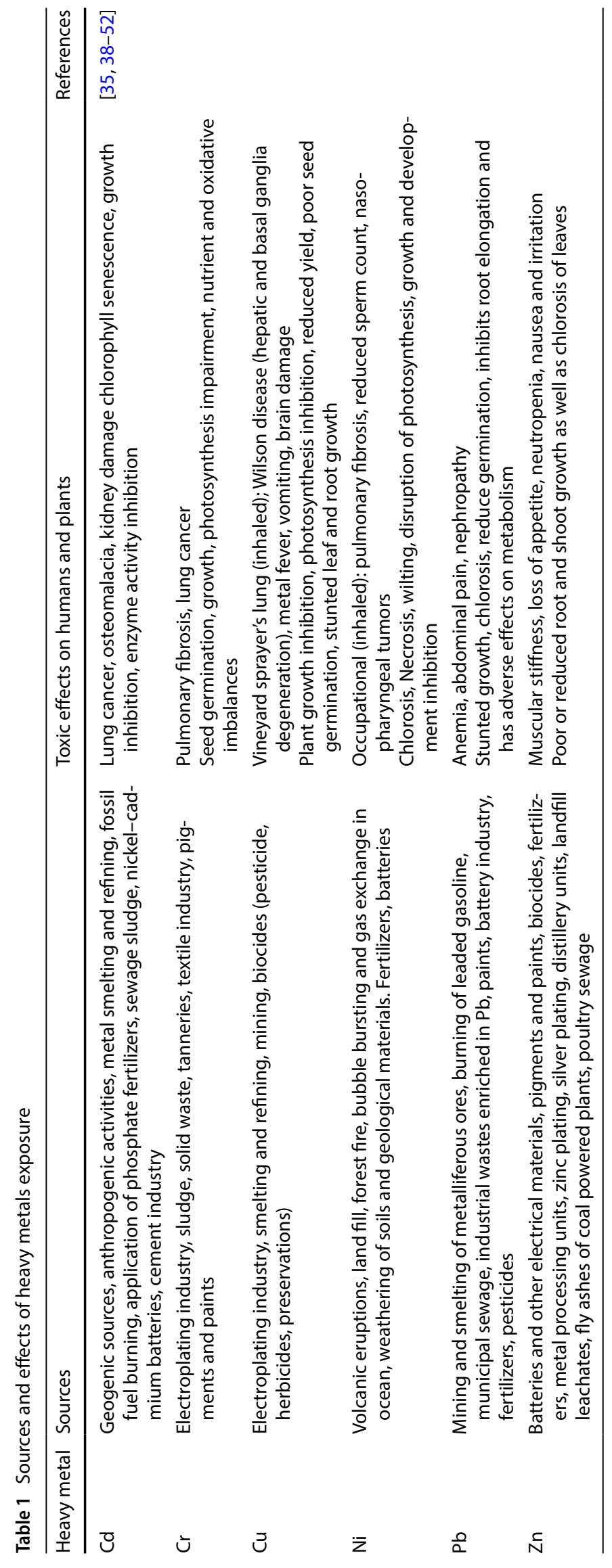




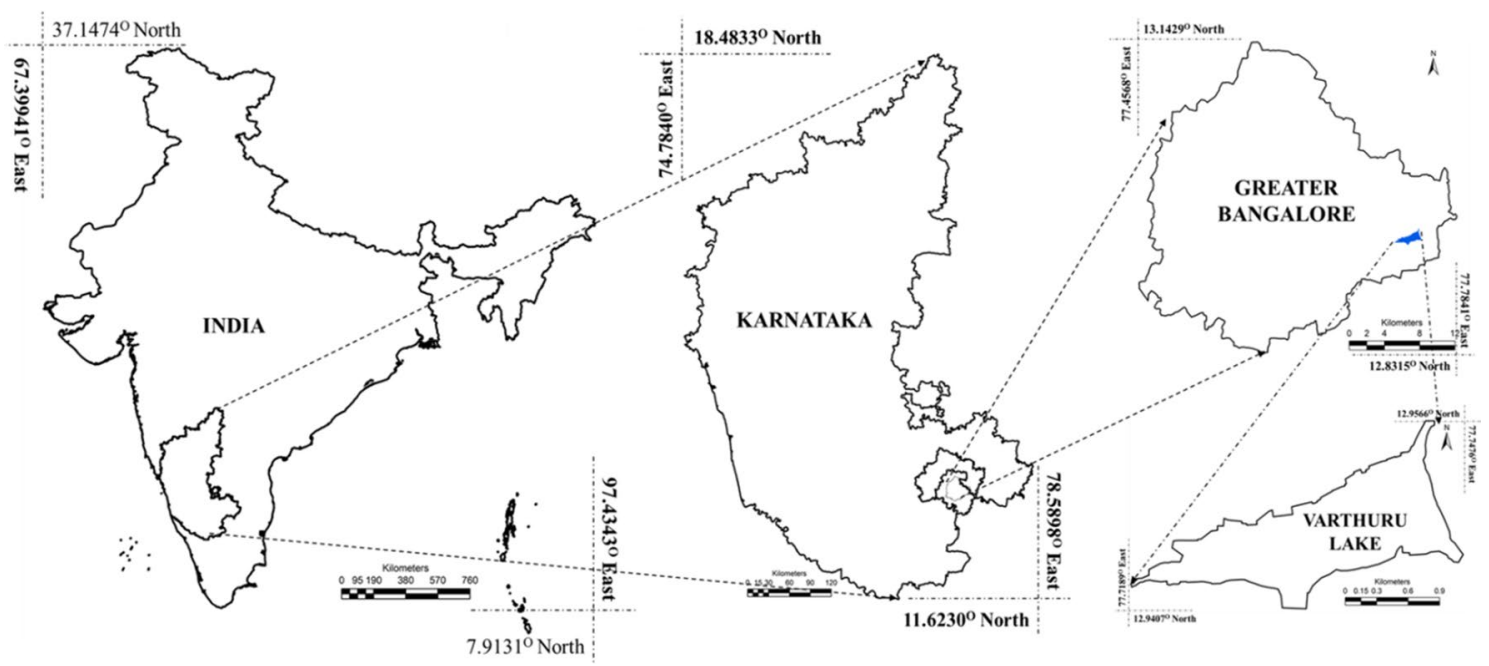

Fig. 1 Study area_-Varthur Lake, Greater Bangalore, Karnataka State, India

an increase in built-up (paved surfaces: buildings, roads, etc.) from $3.8 \%$ (1973) to $89 \%$ (2016) with a sharp decline in vegetation (58.7-6.1\%), water bodies $(4.5-1.2 \%)$ and other (open lands, agriculture) land uses (33.1-5.0\%) in the catchment [56].

\subsection{Macrophyte and sediment sample collection}

Representative samples of macrophytes and sediment were collected from the inlet to outlet regions of the lake, following quadrat-based transact method (quadrat of $1 \mathrm{~m}^{2}$ ) (Fig. 2). Three to five samples were collected in each quadrat. Random sampling method was used for collection of macrophytes. The major species of macrophytes in this lake were Eichhornia crassipes and Alternanthera philoxeroides. Macrophytes were identified based on the standard taxonomic literatures [57] and stored in polythene bags. Approximately $1 \mathrm{~kg}$ of sediment (in triplicates) was collected at a depth of $0-20 \mathrm{~cm}$ at each sampling locations with the help of a cylindrical PVC cores with $5 \mathrm{~cm}$ of internal diameter.

\subsection{Sample preparation and analysis}

Collected macrophytes were washed to remove adhered sediments and epiphytes and segregated based on species. Shoot and root of each sample were separated and oven dried at $60^{\circ} \mathrm{C}$ for $2-3$ days until the attainment of constant
Fig. 2 Sampling locations of macrophytes and sediments in Varthur lake

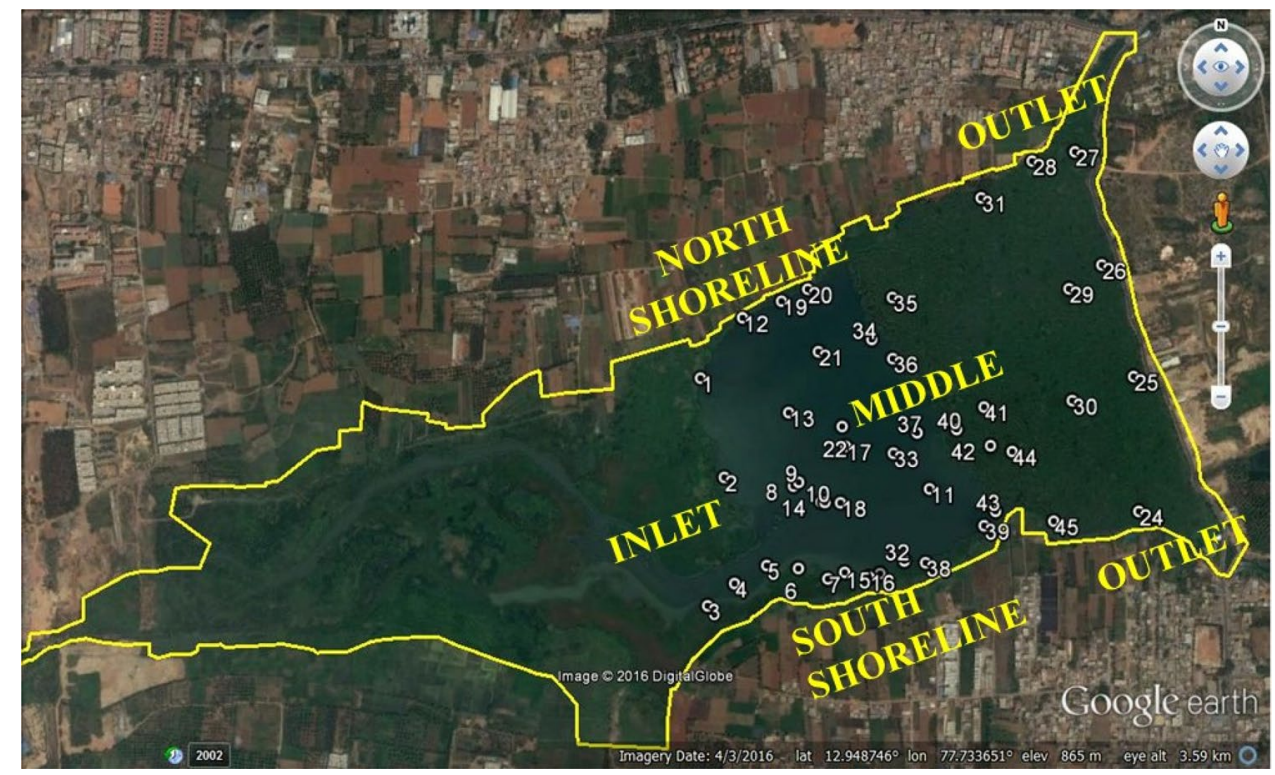


weight. It is then powdered using mixer/grinder and sieved to get fine powders. The replicates of each sample were used for nutrient analysis. The samples were analyzed for $C$, $\mathrm{H}$ and $\mathrm{N}$ using TRUE-SPEC CHN Analyzer. Sediments were airdried and sieved to remove coarse debris. Sediment samples were pulverized using a mortar and sieved to get fine powder. Nutrient analyses in sediment samples were assessed through TRUE-SPEC CHN Analyzer like macrophytes.

\subsection{Heavy metal analysis}

Pulverized sediment sample $(0.5 \mathrm{~g})$ was acid digested with 3:1 (v/v) $\mathrm{HCl}-\mathrm{HNO}_{3}$, evaporated to $2 \mathrm{ml}$, filtered using $0.45-$ $\mu \mathrm{m}$ filter paper and diluted to $50 \mathrm{ml}$ using double distilled water [58] for heavy metal analysis. Macrophyte samples were acid digested with triacid mixture $\left(\mathrm{HNO}_{3}: \mathrm{H}_{2} \mathrm{SO}_{4}: \mathrm{HClO}_{4}\right.$ in 5:1:1) until transparent solution was obtained. Flame atomic absorption spectrophotometry (GBC Avanta version 1.31) was used for analysis of six heavy metals $(\mathrm{Cd}, \mathrm{Cr}, \mathrm{Cu}$, $\mathrm{Ni}, \mathrm{Pb}$ and $\mathrm{Zn}$ ) in samples along with the reference reagent blanks and standards (Merck, USA).

\subsection{Bioconcentration factor (BCF)}

Bioconcentration factor (BCF) in macrophytes is the ratio of heavy metal concentration in the plant to that in the sediment at a sampling location (Eq. 1). Higher values of BCF indicate the easy assimilation of heavy metal by macrophytes from sediments and the higher possibility of heavy metal redistribution in the environment [59]. BCF expresses the ability of a plant to uptake a specific element from sediments and subsequent accumulation in its tissues. Higher BCF values imply of good bioaccumulation or accumulation capability of macrophytes. A BCF value higher than one indicates that a particular plant species is aiding as a hyper-accumulator of trace elements [60].

Bio - concentration factor (BCF)

$$
=\frac{\text { Heavy metal content in macrophytes }}{\text { Heavy metal content in sediment }}
$$

\subsection{Translocation factor (TF)}

Translocation factor (TF) describes the efficiency of a plant to translocate metal from its root to shoot and is computed as the ratio of concentration $(\mathrm{mg} / \mathrm{kg}$ ) of metal in plant shoot to the concentration of the same metal in plant root (Eq. 2). Higher TF values indicate higher capacity of mobility [61].

Translocation factor (TF)

$$
=\frac{\text { Heavy metal content in shoot of macrophytes }}{\text { Heavy metal content in root of macrophytes }}
$$

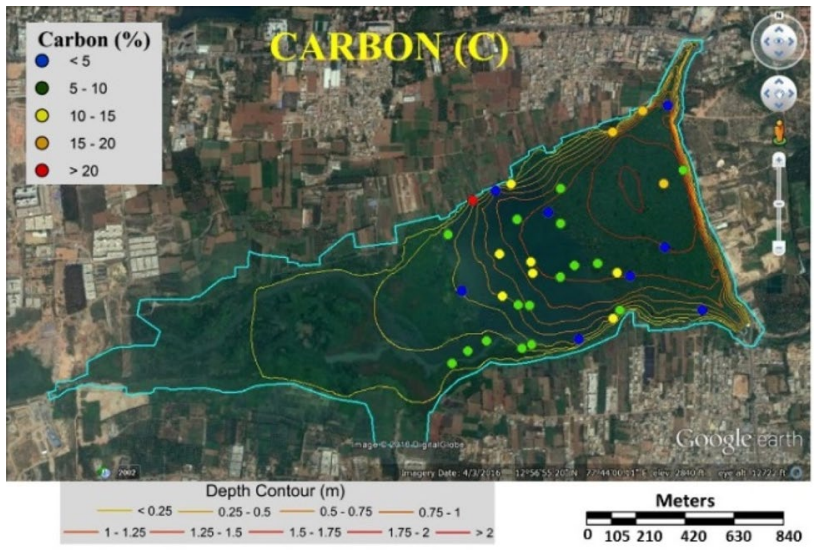

Fig. 3 Carbon content in sediment samples

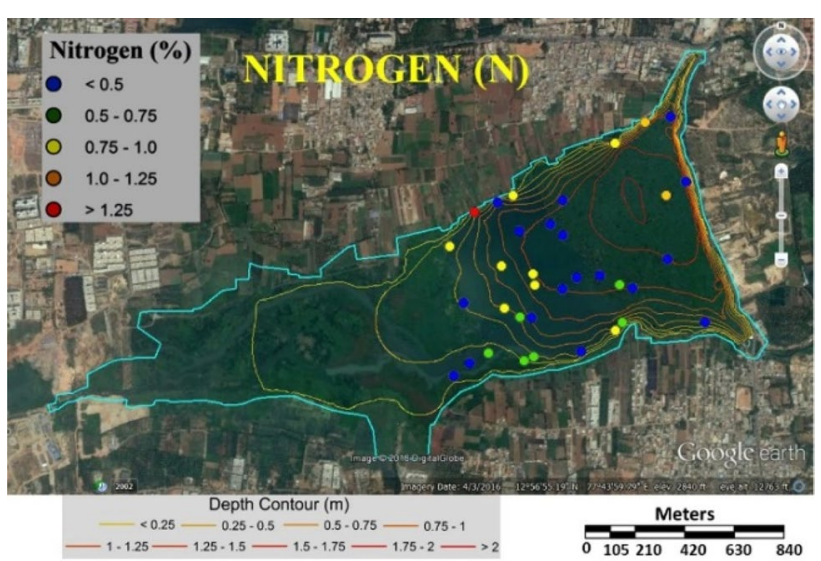

Fig. 4 Nitrogen content in sediment samples

\section{Results}

\subsection{Total carbon and nitrogen in sediment}

Carbon values ranged from $1.58 \mathrm{~g} / 100 \mathrm{~g}$ dry weight (V44) to $21.1 \mathrm{~g} / 100 \mathrm{~g}$ dry weight (V12) in the sediment samples of Varthur lake. Higher $C$ values were in the samples of northwest and northeast shoreline side of the lake (Fig. 3) at a depth of $0.25-1 \mathrm{~m}$, and lower concentrations were found in the middle and outlet regions. Nitrogen values as indicated in Fig. 4 ranged from $0.05 \mathrm{~g} / 100 \mathrm{~g}$ dry weight (V27) to $1.37 \mathrm{~g} / 100 \mathrm{~g}$ dry weight (V12), and the spatial variations in $\mathrm{N}$ concentrations are similar to carbon. $\mathrm{C}: \mathrm{N}$ ratio ranging from 4.26 (V44) to 56.38 (V27) corroborates that organic matter is of terrestrial sources. It was observed that the middle regions of the lake had a higher $\mathrm{C}: \mathrm{N}$ value than the other regions. 
Table 2 Carbon (C) and nitrogen $(\mathrm{N})$ content in sediment and macrophyte samples of Varthur lake
Table 3 Mean, range and critical concentration of heavy metal $(\mathrm{mg} / \mathrm{kg})$ in sediments of Varthur lake

\begin{tabular}{|c|c|c|c|c|}
\hline \multirow[t]{2}{*}{ Sample } & \multicolumn{2}{|c|}{$\mathrm{N}$ (g/100 g dry weight) } & \multicolumn{2}{|c|}{$\mathrm{C}$ (g/100 g dry weight) } \\
\hline & Range & Mean & Range & Mean \\
\hline Sediment & $0.05-1.4$ & 0.57 & $1.57-21.1$ & 8.56 \\
\hline Eichhornia crassipes shoot & $2.57-4.34$ & 3.59 & $33.87-37.51$ & 34.84 \\
\hline Eichhornia crassipes root & $2.84-4.32$ & 3.2 & 29.74-35.97 & 33.65 \\
\hline Alternanthera philoxeroides shoot & $4.12-5.27$ & 4.85 & $33.98-35.78$ & 34.61 \\
\hline Alternanthera philoxeroides root & $3.16-4.43$ & 3.80 & $35.29-37.2$ & 36.25 \\
\hline Typha angustifolia shoot & $1.2-3.5$ & 1.99 & $30.1-32.2$ & 31.14 \\
\hline Typha angustifolia root & $2.1-4.25$ & 2.92 & $32.6-35.5$ & 34.69 \\
\hline Colocasia esculenta shoot & $4-4.46$ & 4.26 & $36.5-38.5$ & 37.51 \\
\hline Colocasia esculenta root & $3.75-4$ & 3.88 & $38.08-38.41$ & 38.25 \\
\hline
\end{tabular}

\begin{tabular}{lllllll}
\hline Metal & Mean (range) (mg/kg) & CPCB (2001) & TEL [62] & PEL [62] & $\begin{array}{l}\text { Critical soil } \\
\text { concentration } \\
{[63]}\end{array}$ & $\begin{array}{l}\text { Uncontami- } \\
\text { nated sedi- } \\
\text { ments [48] }\end{array}$ \\
\hline $\mathrm{Cd}$ & $5.82(1.4-23.7)$ & $\mathrm{BDL}$ & 0.596 & 3.53 & $3-8$ & - \\
$\mathrm{Cr}$ & $101.92(36.5-161.7)$ & 389.3 & 37.3 & 90 & $75-100$ & $12-44$ \\
$\mathrm{Cu}$ & $210.57(86.5-421.6)$ & 113 & 35.7 & 197 & $60-125$ & - \\
$\mathrm{Ni}$ & $54.76(26.7-80)$ & 54.5 & 35 & 91.3 & 100 & $1-20$ \\
$\mathrm{~Pb}$ & $45.26(23.4-59.9)$ & 64.9 & 18 & 36 & $100-400$ & $2-50$ \\
$\mathrm{Zn}$ & $131.65(26.8-352.9)$ & - & 123 & 315 & $70-400$ & $1-50$ \\
\hline
\end{tabular}

CPCB Central Pollution Control Board, TEL threshold effect level, PEL probable effect level

\subsection{Total carbon and nitrogen in macrophyte samples}

Carbon and nitrogen content (range and mean) in shoot and root of macrophyte samples is given in Table 2. Carbon content in studied macrophyte samples ranged from $29.74 \mathrm{~g} / 100 \mathrm{~g}$ dry weight to $38.5 \mathrm{~g} / 100 \mathrm{~g}$ dry weight. Eichhornia crassipes and Alternanthera philoxeroides shoot had higher C content at sampling location V2 (inlet), while V15 (south shoreline) had lowest. Average $C$ content in the shoots of Eichhornia crassipes is about $34.2 \mathrm{~g} / 100 \mathrm{~g}$ dry weight, and Alternanthera philoxeroides is $34.6 \mathrm{~g} / 100 \mathrm{~g}$ dry weight. C content in roots of Eichhornia crassipes had higher values in V34 (north shoreline) and lowest in V3 (south shoreline). Carbon content in roots of Alternanthera philoxeroides was lowest at V2 and highest at V27. C values (shoot and root) of Colocasia esculenta and Typha angustifolia were higher at V12 (north shoreline) and lower at V45 (outlet), respectively.

The range of nitrogen in macrophyte samples was 1.2-5.27 g/100 g dry weight. Nitrogen content in Eichhornia crassipes shoot was higher at south shoreline (V7: $4.3 \mathrm{~g}$ ) and lower at north shoreline (V12: $2.6 \mathrm{~g}$ ). The average value of $\mathrm{N}$ in Eichhornia crassipes shoot is $3.59 \mathrm{~g} / 100 \mathrm{~g}$ dry weight and $3.2 \mathrm{~g} / 100 \mathrm{~g}$ dry weight in roots. The highest

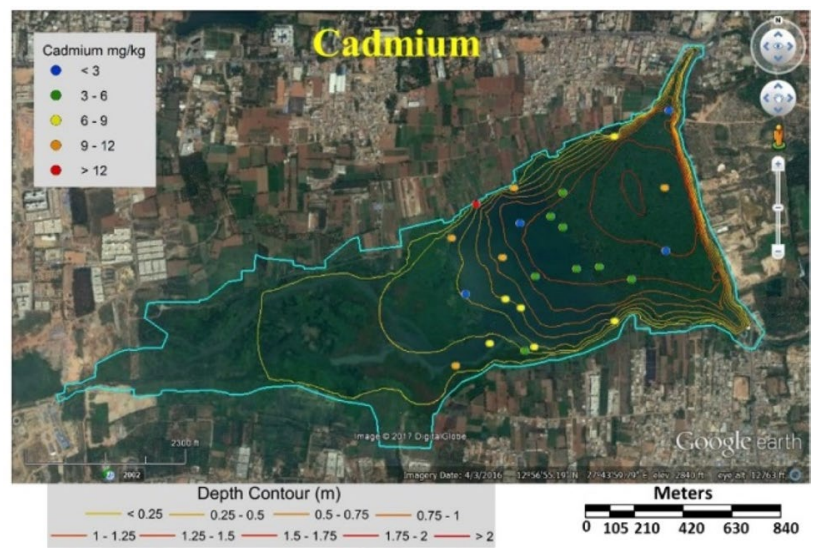

Fig. 5 Concentration of cadmium in sediment samples

$\mathrm{N}$ content in Eichhornia crassipes root was found at V27, and $\mathrm{V} 3 \mathrm{had}$ the lowest $\mathrm{N}$ content. Alternanthera philoxeroides shoot $(4.8 \mathrm{~g})$ and root $(3.8 \mathrm{~g})$ had highest and lowest nitrogen content at V2 and V27, respectively. In case of Colocasia esculenta and Typha angustifolia, the $\mathrm{N}$ content (above ground and below ground parts) was highest at V12 and lowest at V45 (Fig. 4). 


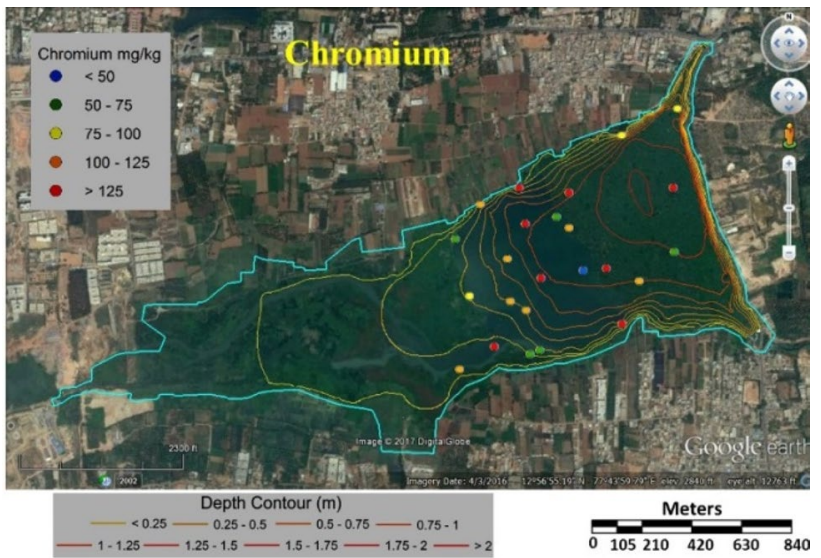

Fig. 6 Concentration of chromium in sediment samples

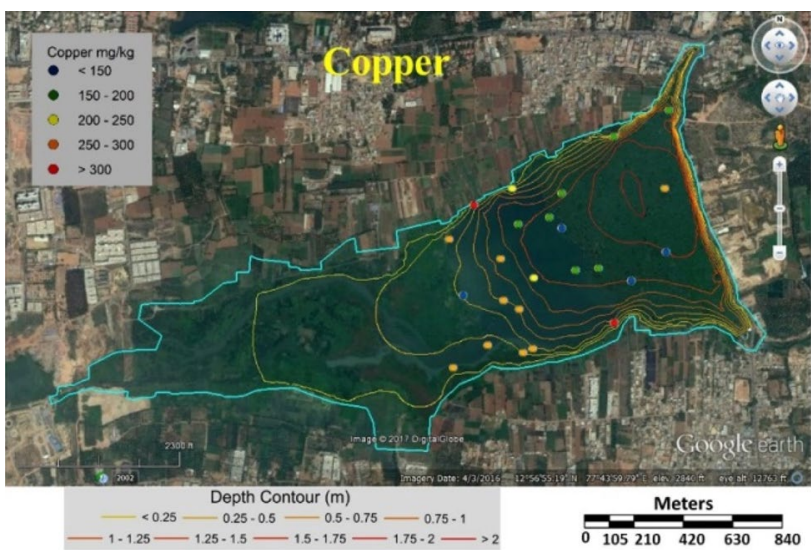

Fig. 7 Concentration of copper in sediment sample

\subsection{Heavy metal concentration in sediment}

Table 3 lists heavy metal concentrations in sediment samples. The mean concentration of all metals in sediments were above threshold effect level (TEL) and was in the order $\mathrm{Cu}>\mathrm{Zn}>\mathrm{Cr}>\mathrm{Ni}>\mathrm{Pb}>\mathrm{Cd}$. Cadmium content in sediments were above TEL and probable effect level (PEL) with V12 and V36 (middle) having highest and lowest (Fig. 5). Chromium concentration was lowest in middle (V37) and highest at northwest shoreline (V21) (Fig. 6). Copper concentration in sediment samples was in the range $86.5-421.6 \mathrm{mg} / \mathrm{kg}$, which are above critical ranges. The inlet and shoreline regions had higher accumulation of copper (highest at northwest shoreline) while the lowest concentrations were in middle regions (Fig. 7). Samples from the middle region (V36) had the lowest concentration, and northwest shoreline sample (V12) had the highest concentration of lead (Fig. 8). Nickel concentration in sediment samples is in the range of $26.7-80 \mathrm{mg} / \mathrm{kg}$ with

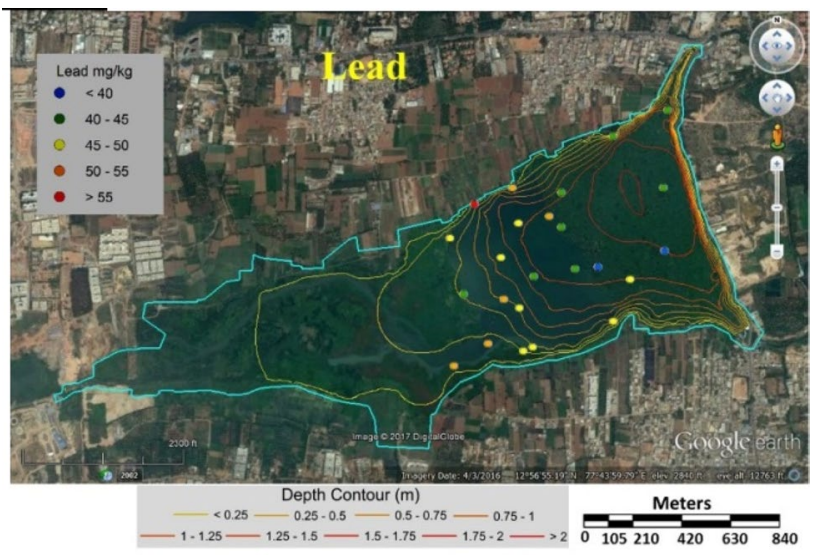

Fig. 8 Concentration of lead in sediment samples of Varthur lake

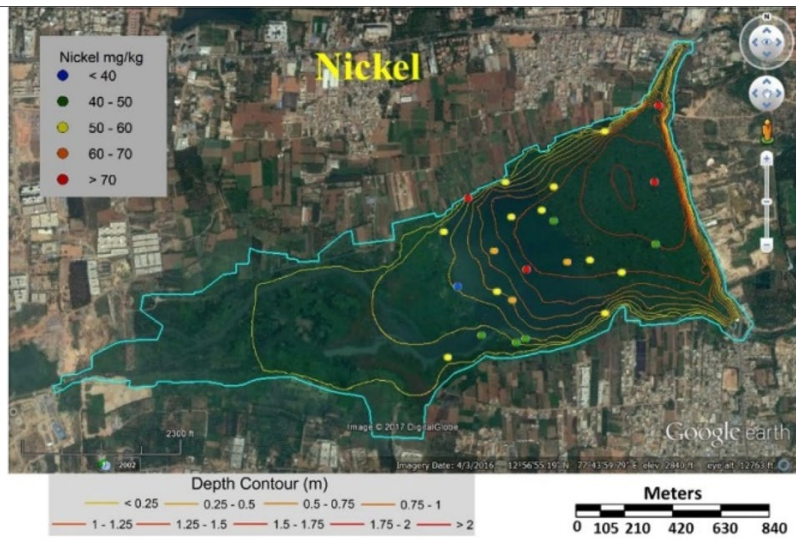

Fig. 9 Concentration of nickel in sediment samples of Varthur lake

mean value of $54.76 \mathrm{mg} / \mathrm{kg}$ (Table 3, Fig. 9), and all samples are within critical level and PEL. The highest nickel concentration in sediment samples was recorded at northwest shoreline (V12) and the lowest in the samples of inlet and middle (Fig. 9). Zinc in the sediment samples ranges from 26.8 to $352.9 \mathrm{mg} / \mathrm{kg}$ (Table 3, Fig. 10) with an average value of $131.65 \mathrm{mg} / \mathrm{kg}$, which is little higher than the earlier reports [40] and is within the critical range in all the samples. The highest zinc concentration was in the sample at northwest shoreline (V12) and the lowest in near inlet sample (V5) (Fig. 10).

\subsection{Heavy metal concentration in macrophytes}

Tables 4 and 5 provide heavy metal concentrations in macrophytes samples, which highlight the relative concentrations were $\mathrm{Cu}>\mathrm{Zn}>\mathrm{Cr}>\mathrm{Pb}>\mathrm{Ni}>\mathrm{Cd}$ in macrophytes. Cadmium concentration in macrophytes samples was higher in Typha angustifolia root and lower in Eichhornia crassipes shoot. The order of accumulation in macrophytes was 


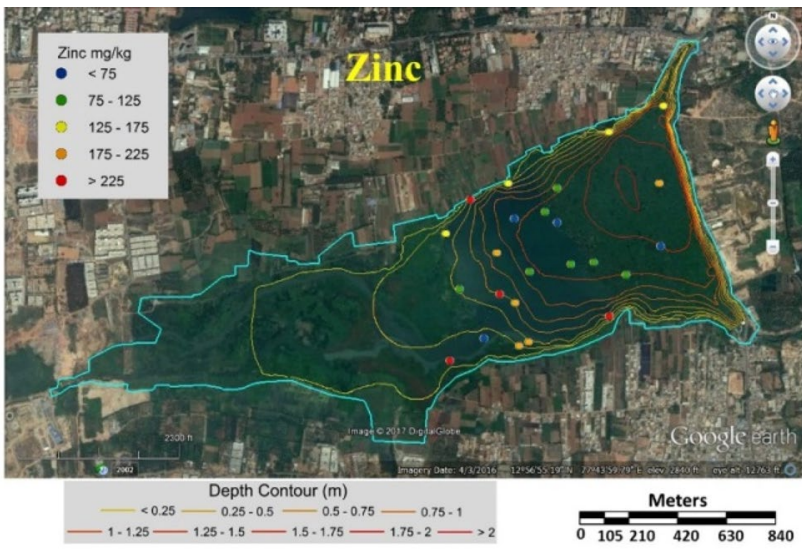

Fig. 10 Concentration of zinc in sediment samples of Varthur lake

Table 4 Comparison of heavy metal $(\mathrm{mg} / \mathrm{kg}$ ) in macrophytes of Varthur lake with critical and normal range in plants

\begin{tabular}{lllll}
\hline Metal & $\begin{array}{l}\text { Mean (range) }(\mathrm{mg} / \\
\mathrm{kg})\end{array}$ & $\begin{array}{l}\mathrm{WHO}^{\mathrm{a}} \\
\text { stand- } \\
\text { ard }\end{array}$ & $\begin{array}{l}\text { Critical range } \\
\text { in plants [63] }\end{array}$ & $\begin{array}{l}\text { Normal range } \\
\text { in plants [63] }\end{array}$ \\
\hline $\mathrm{Cd}$ & $0.21(0-0.8)$ & 0.5 & $5-30$ & $0.1-2.4$ \\
$\mathrm{Cr}$ & $42.33(34-54.8)$ & 1.3 & $5-30$ & $0.03-14$ \\
$\mathrm{Cu}$ & $66.81(21.3-263.5)$ & 40 & $5-30$ & $1-5$ \\
$\mathrm{Ni}$ & $8.44(3.5-17.1)$ & 10 & $10-100$ & $0.02-5$ \\
$\mathrm{~Pb}$ & $21.9(8.7-56.7)$ & 2.0 & $30-300$ & $0.2-20$ \\
$\mathrm{Zn}$ & $64.76(14.8-155.5)$ & 60 & $100-400$ & $1-400$ \\
\hline
\end{tabular}

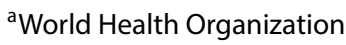

Typha angustifolia $>$ Eichhornia crassipes $>$ Alternanthera philoxeroides $>$ Colocasia esculenta (Table 5). Chromium in macrophytes was in the range of 34-54.8 $\mathrm{mg} / \mathrm{kg}$ (mean$42.33 \mathrm{mg} / \mathrm{kg}$ ) (Table 4) with lowest in Typha angustifolia root and higher in Eichhornia crassipes shoot (Table 5). Colocasia esculenta had highest concentration followed by Eichhornia crassipes, Alternanthera philoxeroides and Typha angustifolia (Table 5). Chromium content in all macrophyte samples exceeded critical limits. The concentration of copper was maximum in Alternanthera philoxeroides shoot and minimum in Eichhornia crassipes shoot (Table 5). Lead concentration ranges from 8.7 to $56.7 \mathrm{mg} /$ $\mathrm{kg}$ with mean value of $21.9 \mathrm{mg} / \mathrm{kg}$ with concentrations in Alternanthera philoxeroides > Eichhornia crassipes > Typha angustifolia > Colocasia esculenta (Table 5). Colocasia esculenta root had lowest concentration, and Alternanthera philoxeroides shoot had highest concentration of lead. Alternnathera philoxeroides and Eichhornia crassipes had lead concentrations in critical range. Nickel content was lowest in Colocasia esculenta and highest in Typha angustifolia root and was exceeding the critical range of $5 \mathrm{mg} /$ $\mathrm{kg}$ in most of the samples. Concentrations of nickel was
Table 5 Heavy metal concentration in macrophytes (mean \pm SD) of Varthur lake

\begin{tabular}{|c|c|c|c|}
\hline Metal & Plant & Shoot & Root \\
\hline \multirow[t]{4}{*}{$\mathrm{Cd}$} & Eichhornia crassipes & $0.10 \pm .05$ & $0.17 \pm 0.15$ \\
\hline & $\begin{array}{l}\text { Alternanthera philox- } \\
\text { eroides }\end{array}$ & $0.15 \pm 0.08$ & $0.1 \pm 0$ \\
\hline & Colocasia esculenta & $0.1 \pm 0.04$ & $0.1 \pm 0.02$ \\
\hline & Typha angustifolia & $0.2 \pm 0.07$ & $0.7 \pm 0.06$ \\
\hline \multirow[t]{4}{*}{$\mathrm{Cr}$} & Eichhornia crassipes & $44.7 \pm 5.99$ & $42.37 \pm 3.85$ \\
\hline & $\begin{array}{l}\text { Alternanthera philox- } \\
\text { eroides }\end{array}$ & $45.03 \pm 3.43$ & $37.85 \pm 5.44$ \\
\hline & Colocasia esculenta & $38.1 \pm 3.23$ & $50.8 \pm 3.56$ \\
\hline & Typha angustifolia & $43.8 \pm 3.59$ & $33 \pm 3.21$ \\
\hline \multirow[t]{4}{*}{$\mathrm{Cu}$} & Eichhornia crassipes & $58.46 \pm 31.05$ & $89.43 \pm 12.48$ \\
\hline & $\begin{array}{l}\text { Alternanthera philox- } \\
\text { eroides }\end{array}$ & $148.18 \pm 109.07$ & $103.05 \pm 10.25$ \\
\hline & Colocasia esculenta & $28.9 \pm 3.89$ & $44.4 \pm 5.66$ \\
\hline & Typha angustifolia & $42.1 \pm 6.23$ & $32.1 \pm 2.13$ \\
\hline \multirow[t]{4}{*}{$\mathrm{Ni}$} & Eichhornia crassipes & $6.18 \pm 2.57$ & $12.57 \pm 0.65$ \\
\hline & $\begin{array}{l}\text { Alternanthera philox- } \\
\text { eroides }\end{array}$ & $5.57 \pm 0.71$ & $7.85 \pm 2.19$ \\
\hline & Colocasia esculenta & $5.6 \pm 1.62$ & $4.95 \pm 1.11$ \\
\hline & Typha angustifolia & $7.7 \pm 2.26$ & $16.2 \pm 0.56$ \\
\hline \multirow[t]{4}{*}{$\mathrm{Pb}$} & Eichhornia crassipes & $22.7 \pm 5.18$ & $24.8 \pm 2.39$ \\
\hline & $\begin{array}{l}\text { Alternanthera philox- } \\
\text { eroides }\end{array}$ & $32.42 \pm 18.65$ & $33.2 \pm 18.95$ \\
\hline & Colocasia esculenta & $13.5 \pm 2.87$ & $9.25 \pm 0.25$ \\
\hline & Typha angustifolia & $20.5 \pm 5.65$ & $18.8 \pm 6.22$ \\
\hline \multirow[t]{4}{*}{$\mathrm{Zn}$} & Eichhornia crassipes & $38.78 \pm 39.16$ & $121.67 \pm 6.85$ \\
\hline & $\begin{array}{l}\text { Alternanthera philox- } \\
\text { eroides }\end{array}$ & $28.6 \pm 6.54$ & $139.45 \pm 22.7$ \\
\hline & Colocasia esculenta & $20.6 \pm 2.96$ & $28.85 \pm 4.74$ \\
\hline & Typha angustifolia & $23.1 \pm 3.96$ & $117 \pm 5.87$ \\
\hline
\end{tabular}

higher in Typha angustifolia $>$ Eichhornia crassipes $>$ Alternanthera philoxeroides $>$ Colocasia esculenta (Table 5). Zinc in macrophyte samples were within normal and critical range [63]. Alternanthera philoxeroides shoot had the highest concentration, and Eichhornia crassipes shoot had the lowest concentration of zinc. Overall, Alternanthera philoxeroides was higher accumulator of zinc followed by Eichhornia crassipes, Typha angustifolia and Colocasia esculenta (Table 5).

\subsection{Bioconcentration and translocation factor}

Bioconcentration factor (BCF) and translocation factor (TF) were used for understanding the heavy metal distribution pattern in macrophytes of Varthur lake (Figs. 11, 12). Bioconcentration factors for $\mathrm{Pb}, \mathrm{Zn}, \mathrm{Ni}, \mathrm{Cr}, \mathrm{Cd}$ and $\mathrm{Cu}$ ranged from 0.5 to $1.45,0.38$ to $1.28,0.19$ to $0.28,0.75$ to $0.9,0.13$ to $0.27,0.35$ to 1.14 , respectively (Fig. 11 ) with 


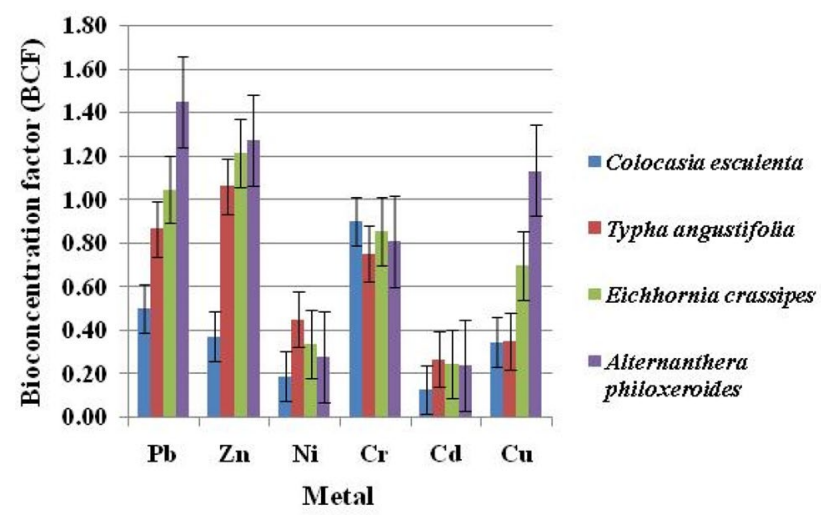

Fig. 11 Bioconcentration factor (BCF) of macrophyte samples

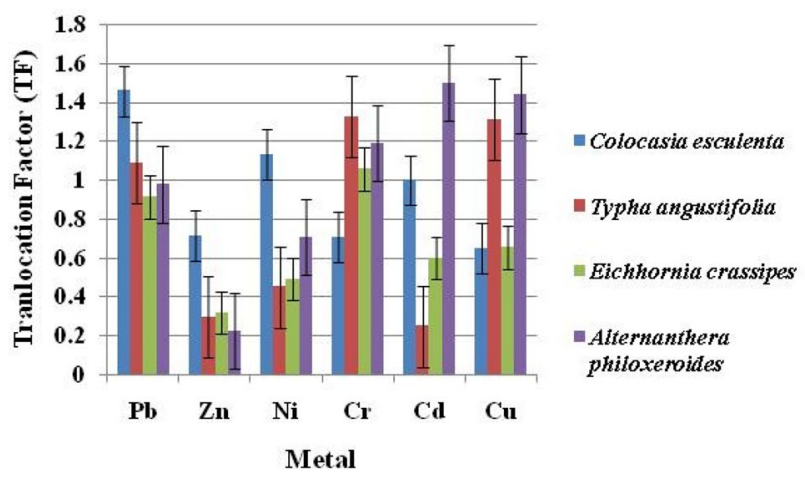

Fig. 12 Translocation factor (TF) of macrophyte samples

$\mathrm{Zn}>\mathrm{Pb}>\mathrm{Cr}>\mathrm{Cu}>\mathrm{Ni}>\mathrm{Cd}$. Higher BCF for lead, zinc and copper was in Alternanthera philoxeroides, while higher BCF for nickel and cadmium in Typha angustifolia and for Chromium in Colocasia esculenta. The translocation factor for $\mathrm{Pb}, \mathrm{Zn}, \mathrm{Ni}, \mathrm{Cr}, \mathrm{Cd}$ and $\mathrm{Cu}$ ranged from 0.9 to 1.45 , 0.22 to $0.71,0.45$ to $1.13,0.7$ to $1.32,0.25$ to 1.5 and 0.65 to 1.43 , respectively (Fig. 12) and the translocation factor of $\mathrm{Pb}>\mathrm{Cr}>\mathrm{Cu}>\mathrm{Cd}>\mathrm{Ni}>\mathrm{Zn}$. Among the studied macrophytes, Colocasia esculenta had higher TF for lead, zinc and nickel. Alternanthera philoxeroides had maximum TF for cadmium and copper while Typha angustifolia had maximum TF for chromium.

\section{Discussion}

\subsection{Total carbon and nitrogen in sediment and macrophytes}

Nutrients such as carbon and nitrogen play a vital role in maintaining trophic levels in lake ecosystems. Assessment of organic matter concentrations helps in understanding the nutrient dynamics in a lake ecosystem. The organic matter in sediments is given by the ratio of total organic carbon to total nitrogen ( $\mathrm{C} / \mathrm{N}$ ratio), which aids in estimating the percentage of autochthonous planktonic matter in sediments [64], and $\mathrm{C} / \mathrm{N}$ ratios in lake sediments reflect the composition of organic matter $[65,66]$. Increase in cellulose content increases $\mathrm{C} / \mathrm{N}$ ratio. $\mathrm{C} / \mathrm{N}$ ratios of 5 to 6 in phytoplankton and zooplankton are due to proteins consisting primarily of nitrogen compounds. The $\mathrm{C} / \mathrm{N}$ ratio in the terrestrial vascular plants is 15 or $>20$ [67], and in the case of macrophytes $\mathrm{C} / \mathrm{N}$ ratio is about 39.4. Variations in $\mathrm{C}: \mathrm{N}$ ratios within lake sediments help in determining the historical changes in the sources of organic matter. Increases in C: $\mathrm{N}$ ratio in sediment profiles have been useful to interpret the period (in a lake's history) when sediments received a high proportion of terrestrial organic matter [68].

Higher $\mathrm{C}$ values in sediment were in the northwest and northeast shoreline side of the lake, attributed to higher terrestrial $C$ sources of domestic sewage from the urbanized pockets of the catchment. Lower $C$ values in the lake sediments were observed at southern side and outlets of the lake, where depth is greater than $1 \mathrm{~m}$. Similar $\mathrm{C}$ and $\mathrm{N}$ distributions were reported in the earlier studies [66]. Higher C: $\mathrm{N}$ in middle regions is due to the sustained inflow from the neighboring residential layouts on both sides and the middle regions are with stagnant water. This highlights the storm water drains are being misused with the discharge of sewage, contributing terrestrial organic matter into the lake.

Macrophyte sample analyses revealed that higher concentration of carbon was in Colocasia esculenta root and lowest in Eichhornia crassipes root, and these values were lesser compared to earlier study [55]. Emergent macrophytes had higher carbon concentration than floating plants because of fibers in developed support system [14]. Nitrogen was higher in Alternanthera philoxeroides shoot and lowest in Typha angustifolia shoot. The results of this study showed higher nitrogen content than earlier report [55].

\subsection{Heavy metal concentration in sediment and macrophytes}

Tables 6 and 7 compare metal concentrations in sediment and macrophytes of Varthur lake with various other studies. Cadmium is of most concern due to the greatest mobility in soil environment [69] and is widespread heavy metal, which is extremely toxic to humans and plants [70]. Cadmium enters aquatic environment through anthropogenic sources like industrial effluent and agricultural runoff [71]. Cadmium concentration in this study was higher compared to the earlier study [40] and above PEL and critical 
Table 6 Comparison of heavy metal $(\mathrm{mg} / \mathrm{kg})$ in sediments of the current study with other studies

\begin{tabular}{|c|c|c|c|c|c|c|c|}
\hline \multirow[t]{2}{*}{ Name of the lake } & \multicolumn{6}{|c|}{ Metal concentration $(\mathrm{mg} / \mathrm{kg})$} & \multirow[t]{2}{*}{ References } \\
\hline & $\mathrm{Cd}$ & $\mathrm{Cr}$ & $\mathrm{Cu}$ & $\mathrm{Ni}$ & $\mathrm{Pb}$ & $\mathrm{Zn}$ & \\
\hline Varthur lake, Bangalore & $5.8(1.40-23.7)$ & $102(36.5-162)$ & $211(86.5-422)$ & $54.8(26.7-80.0)$ & $45.3(23.4-59.9)$ & $132(26.8-353)$ & Present study \\
\hline Varthur lake, Bangalore & BDL-17.3 & BDL-21.4 & $131-134$ & $16.2-68.0$ & $4.40-88.5$ & $25.7-220$ & {$[40]$} \\
\hline $\begin{array}{l}\text { Bellandur lake, Ban- } \\
\text { galore }\end{array}$ & $1.60-55.3$ & 33.9-199 & $105-1148$ & $15.1-138$ & $31.2-208$ & $126-2001$ & {$[2]$} \\
\hline Wular lake & - & 160.27 & 47.33 & 57 & - & - & [74] \\
\hline Ramgarh lake & 0.015 & - & 1.33 & - & 0.27 & 2.28 & {$[75]$} \\
\hline $\begin{array}{l}\text { Veeranam lake, Chen- } \\
\text { nai }\end{array}$ & $0.20-3.90$ & $40.0-150$ & $65.0-125$ & $34.0-95.0$ & $20.0-41.0$ & $65.0-599$ & [76] \\
\hline $\begin{array}{l}\text { ICRISAT lake, } \\
\text { Patancheru }\end{array}$ & $0-0.1$ & $16.6-75.4$ & $6.1-40.3$ & $6.7-41.5$ & $4.2-19.6$ & $3.8-55.2$ & [77] \\
\hline Anchar lake, Kashmir & $0.70-3.60$ & $3.10-8.70$ & $2.80-28.7$ & $2.10-10.1$ & $0.40-4.30$ & $1.40-13.8$ & [73] \\
\hline Yercaud lake & - & $322-441$ & $480-687$ & 147 & $15.5-48.0$ & $101-258$ & [78] \\
\hline $\begin{array}{l}\text { Akkulam Veli lake, } \\
\text { Thiruvananthapuram }\end{array}$ & - & $49.0-642$ & $1.00-126$ & $5.00-259$ & $18.0-189$ & $19.0-279$ & [79] \\
\hline GB Pant Sagar & $0.30-5.60$ & $0.60-32.3$ & $1.30-30.7$ & $0.30-38.3$ & $1.00-11.0$ & $5.00-59.9$ & {$[80]$} \\
\hline Kolkata wetlands & - & $12-57$ & $17-145$ & $19-37$ & $13-118$ & $80-425$ & [81] \\
\hline Kodaikanal lake & - & 452 & 54.5 & 115 & 44.7 & 113 & {$[82]$} \\
\hline Urban pond, Dhanbad & $1.70-5.00$ & $74.0-109$ & - & - & $23.3-36.0$ & $1055-1804$ & [83] \\
\hline
\end{tabular}

range $[62,63]$. The highest concentration $(23.7 \mathrm{mg} / \mathrm{kg})$ was observed in the northwest shoreline sample (V12) and the lowest (1.4 mg/kg) in the middle sample (V36) (Fig. 5). These values were lower compared to the samples of Bellandur Lake [2]. The outlet and middle region had lower concentration of cadmium compared to other regions (Fig. 5). Chromium is toxic for plants as it alters $\mathrm{N}$ metabolism and impairs protein formation [27]. More than half of the sampling points had critical ranges of chromium. Sediments in the inlet and north shoreline regions had higher concentrations of chromium than other samples (Fig. 6). The present study values were 10 times higher than the earlier reports [40]. Copper concentrations in the current study were higher compared to the earlier study [40] and lower compared to Bellandur Lake [2]. Lead is one of the most toxic metals at low concentrations and non-essential element for plant $[27,72]$. The main source of lead in the sediment is from lead pipes, mixing of gun powder, waste batteries, etc.[73]. Earlier studies [2, 40] recorded lower lead concentrations compared to the present study. Zinc in the sediment samples was little higher than the earlier reports [40]. Plant growth, metabolism and physiology are effected by toxic metal nickel. The concentration of nickel in sediments was` lower than PEL and critical values.

The Varthur lake catchment also receives surface runoff containing fertilizers and pesticides from agriculture and floriculture lands, which is contributing to $\mathrm{Cd}, \mathrm{Pb}$, $\mathrm{Ni}$ in the lake surface sediments. Untreated wastewater from industries such as electroplating, metallurgical, batteries manufacturing, vehicle garages, etc. has contributed to the accumulation of heavy metals ( $\mathrm{Cr}$, $\mathrm{Cu}$. $\mathrm{Cd}$ and $\mathrm{Zn}$ ), which is evident from the analysis of sediment samples at the north shoreline. Among macrophyte samples, Alternanthera philoxeroides and Eichhornia crassipes had higher concentration of all investigated heavy metals.

Plants with high BCF and low TF $(B C F>1$ and TF $<1)$ aid in efficient remediation with phytostabilization, while phytoextraction happens with both BCF and TF > 1 [98]. In the current study, scope for remediation of heavy metals (lead and zinc) through phytostabilization was exhibited by Alternanthera philoxeroides and Eichhornia crassipes, respectively. Alternanthera philoxeroides showed phytoextraction capability of copper. Colocasia esculenta, Typha angustifolia and Alternanthera philoxeroides displayed higher mobility for nickel, chromium and cadmium, respectively (BCF $<1$ and TF $>1$ ).

The study highlights the presence of organic and heavy metals in sediments and macrophytes, indicating contamination due to the sustained inflow of untreated sewage and industrial effluents. Environmental changes in the lake catchment during the past 5 decades due to rapid urbanization have been responsible for the lake contamination. The organic contamination is mainly due to untreated sewage and runoff entering the lake. The metal pollution is due to entry of industrial wastewater and agricultural runoff. The study recommends proper treatment of sewage before letting into the lake to prevent contamination and associated health hazards in the vicinity. 
Table 7 Comparison of heavy metal $(\mathrm{mg} / \mathrm{kg})$ in macrophytes of current study with other studies

\begin{tabular}{|c|c|c|c|c|c|c|c|}
\hline \multirow[t]{2}{*}{ Macrophyte } & \multicolumn{6}{|c|}{ Metal concentration (mg/kg) } & \multirow[t]{2}{*}{ References } \\
\hline & $\mathrm{Cd}$ & $\mathrm{Cr}$ & $\mathrm{Cu}$ & $\mathrm{Ni}$ & $\mathrm{Pb}$ & $\mathrm{Zn}$ & \\
\hline \multirow[t]{14}{*}{ Eichhornia crassipes } & $0.17 \pm 0.15$ & $42.37 \pm 3.9$ & $89.43 \pm 12.5$ & & & & This study \\
\hline & $8(0.72-21.5)$ & $71.5(1.2-160.9)$ & 9.63 (BDL-21.0) & $47.9(26-65.3)$ & $63.4(22-98.5)$ & $42.9(27.4-58.3)$ & {$[40]$} \\
\hline & $1500 \pm 47$ & $309 \pm 13.1$ & $560 \pm 15$ & $260 \pm 8.1$ & $267 \pm 9.0$ & $1400 \pm 74.3$ & {$[84]$} \\
\hline & $9.13 \pm 0.15$ & $8.06 \pm 0.93$ & $92.4 \pm 0.3$ & - & $83.42 \pm 0.7$ & $572.8 \pm 2.3$ & {$[85]$} \\
\hline & 61.5 & - & - & - & 356.2 & - & {$[86]$} \\
\hline & 0.82 & 0.32 & 0.14 & 0.15 & 6.29 & - & [87] \\
\hline & 8.7 & 33.1 & 25.3 & 1077 & 40 & 243 & [88] \\
\hline & - & - & $62.5 \pm 17.5$ & $12.9 \pm 8.4$ & $25.2 \pm 1.2$ & $238.1 \pm 76.4$ & [89] \\
\hline & $8.3-30.9$ & $6.2-133.8$ & - & - & $34.9-80.9$ & - & {$[90]$} \\
\hline & 21.8 & - & 2868 & 253 & - & - & [91] \\
\hline & 128 & 69.3 & - & 78.5 & 256 & - & [92] \\
\hline & 0.79 & - & 44.5 & 28.83 & 9.81 & 709.1 & [93] \\
\hline & - & - & - & - & 13.89 & 140.97 & {$[94]$} \\
\hline & - & $160 \pm 12.0$ & $23.2 \pm 1.7$ & - & $11.5 \pm 1.8$ & $170 \pm 40.6$ & [21] \\
\hline \multirow[t]{4}{*}{ Alternanthera philoxeroides } & $0.15 \pm 0.08$ & $45.03 \pm 3.43$ & $148.2 \pm 109.1$ & $7.85 \pm 2.19$ & $33.2 \pm 18.95$ & $139.5 \pm 22.7$ & This study \\
\hline & $8.5-45.1$ & $0.3-81.3$ & - & - & $46.6-91.8$ & - & {$[90]$} \\
\hline & 16.4 & - & 2839 & 441 & - & - & [91] \\
\hline & - & - & - & - & $53.3-383.3$ & 54-199.5 & {$[95]$} \\
\hline \multirow[t]{5}{*}{ Colocasia esculenta } & $0.1 \pm 0.04$ & $50.8 \pm 3.56$ & $44.4 \pm 5.66$ & $5.6 \pm 1.62$ & $13.5 \pm 2.87$ & $28.85 \pm 4.74$ & This study \\
\hline & $4.16 \pm 1.98$ & - & $28.6 \pm 8.8$ & - & $25.5 \pm 11.6$ & - & {$[96]$} \\
\hline & 3.2 & 1545 & - & 43.6 & 148.5 & - & {$[92]$} \\
\hline & $2.3 \pm 0.5$ & $11.9 \pm 1.0$ & $80.7 \pm 5.8$ & - & - & - & [97] \\
\hline & - & - & - & - & $27.94 \pm 0.45$ & $105.3 \pm 0.09$ & [94] \\
\hline \multirow[t]{4}{*}{ Typha angustifolia } & $0.7 \pm 0.06$ & $43.8 \pm 3.59$ & $42.1 \pm 6.23$ & $16.2 \pm 0.56$ & $20.5 \pm 5.65$ & $117 \pm 5.87$ & This study \\
\hline & 9.5 & 14.5 & 43.2 & 370 & 32.66 & 216 & [88] \\
\hline & - & - & $8.98 \pm 1.7$ & $9.95 \pm 2.9$ & $29.5 \pm 3.4$ & $97.6 \pm 5.2$ & [89] \\
\hline & 1.44 & - & 104.21 & 20.26 & 6.92 & 276.13 & [93] \\
\hline
\end{tabular}

\section{Conclusion}

The nutrient and heavy metal concentration in sediment and macrophyte samples from Varthur lake was assessed through standard protocol of representative samples. Carbon and nitrogen values in sediment were higher at depths ranging from 0.25 to $1 \mathrm{~m}$ and at the northwest and northeast side of the lake. Lower $C$ and $\mathrm{N}$ values were observed in the samples collected at the depth greater than $1 \mathrm{~m}$, at middle and at lake outlets. Among macrophytes, the highest $\mathrm{C}$ and $\mathrm{N}$ were in the shoots of Colocasia esculenta and Alternanthera philoxeroides, respectively. Heavy metals concentrations were higher in the sediment samples of north shoreline and inlets. Alternanthera philoxeroides and Eichhornia crassipes had higher concentrations of heavy metals. Sediment samples had heavy metals in the order $\mathrm{Cu}>\mathrm{Zn}>\mathrm{Cr}>\mathrm{Ni}>\mathrm{Pb}>\mathrm{Cd}$, while in macrophytes samples $\mathrm{Cu}>\mathrm{Zn}>\mathrm{Cr}>\mathrm{Pb}>\mathrm{Ni}>\mathrm{Cd}$. Thus, the Varthur lake acted as a sink to nutrients and metals. The study highlights phytoremediation potential of macrophytes and caution to be exercised while using these macrophytes as either vegetable or fodder to prevent heavy metal contamination in the biotic food chain. The present study also demonstrated the potential of macrophytes and sediments in the removal of nutrients and heavy metals. Hence, taking advantage of phyto- and phycoremediation prospects, constructed wetlands integrated with algal pond at the inlet of each water body would help in the treatment and mitigates contamination of water bodies.

Acknowledgements We are grateful to (1) Gautam and Vasantha Jagadisan Endowment-Lake Rejuvenation Indian Institute of Science, Bangalore 560012; (2) The Ministry of Environment, Forests and Climate Change, Government of India; and (3) UNSD and MoSP, The Ministry of Statistics and Programme Implementation, Government of India, for the financial and infrastructure support. We thank local stakeholders for actively taking part in the scientific discussions and cooperation during field data compilation. We are grateful to Madras Engineering Group, Bangalore, Indian Army for actively supporting the field sampling exercise. We are grateful to the official languages section at IISC for the assistance in language editing. 
Data availability Data used in the analyses are compiled from the field. Data is analyzed and organized in the form of table, which are presented in the manuscript. Also, synthesized data are archived at http://wgbis.ces.iisc.ernet.in/energy/water/paper/researchpaper2. html\#ce, http://wgbis.ces.iisc.ernet.in/biodiversity/.

\section{Compliance with ethical standards}

Conflict of interest We have no conflict of interest either financial or non-financial.

Human and animal rights The research does not involve either humans, animals or tissues.

\section{References}

1. Kiran R, Ramachandra TV (1999) Status of wetlands in Bangalore and its conservation aspects. ENVIS J Hum Settl 16(24):2-10

2. Ramachandra TV, Sudarshan PB, Mahesh MK, Vinay S (2018) Spatial patterns of heavy metal accumulation in sediments and macrophytes of Bellandur Wetland, Bangalore. J Environ Manag 206:1204-1210

3. Abdel-Khalek A (2015) Risk assessment, bioaccumulation of metals and histopathological alterations in Nile tilapia (Oreochromis niloticus) facing degraded aquatic conditions. Bull Environ Contam Toxicol 94(1):77-83

4. Kumari M, Tripathi BD (2015) Efficiency of Phragmites australis and Typha latifolia for heavy metal removal from wastewater. Ecotoxicol Environ Saf 112:80-86

5. Rana V, Maiti SK, Jagadevan S (2016) Ecological risk assessment of metals contamination in the sediments of natural urban wetlands in dry tropical climate. Bull Environ Contam Toxicol 97:407-412

6. Le C, Zha Y, Li Y, Sun D, Lu H, Yin B (2010) Eutrophication of lake waters in China: cost, causes, and control. Environ Manag 45:662-668

7. Vijayaraj R, Achyuthan H (2016) Organic matter source in the freshwater tropical lakes of southern India. Curr Sci 111(1):168-176

8. Clarke A, Weckstrom K, Conley D, Anderson NJ, Adser F, Andren E, De Jonge V, Ellegaard M, Juggins S, Kauppila P (2006) Long term trends in eutrophication and nutrients in the coastal zone. Limnol Oceanogr 51:385-397

9. Meyers PA (2003) Applications of organic geochemistry to paleolimnological reconstructions: a summary of examples from the Laurentian Great Lakes. Org Geochem 34:261-289

10. Sondergaard M, Jensen PJ, Jeppesen E (2001) Retention and internal loading of phosphorus in shallow, eutrophic lakes. Sci World 1:427-442

11. Mitsch WJ, Gosselink JG (2000) Wetlands, 3rd edn. Wiley, New York

12. Barbieri R, Esteves FA (1991) The chemical composition of some aquatic macrophyte species and implications for the metabolism of a tropical lacustrine ecosystem Lobo Reservoir, Sao Paulo, Brazil. Hydrobiologia 213:133-140

13. Henry-silva GG, Pezzato MM, Benassi RF, Camargo AFM (2006) Chemical composition of five species of aquatic macrophytes from lotic ecosystems of the southern coast of the state of Sao Paulo (Brazil). Acta Limnol Bras 13(2):11-17

14. U.S. Environmental Protection Agency (1998) A citizen's guide to phytoremediation. Report No. EPA 542-F-98-011. Office of Solid Waste and Emergency Response, Washington, DC
15. Xie D, Yu D, You W, Wang L (2013) Algae mediate submerged macrophyte response to nutrient and dissolved inorganic carbon loading: a mesocosm study on different species. Chemosphere 93:1301-1308

16. Li L, Zerbe S, Han W, Thevs N, Li W, He P, Schmitt AO, Liu Y, Ji C (2014) Nitrogen and phosphorus stoichiometry of common reed (Phragmites australis) and its relationship to nutrient availability in northern China. Aquat Bot 112:84-90

17. Muller I, Schmid B, Weiner J (2000) The effect of nutrient availability on biomass allocation patterns in 27 species of herbaceous plants. Perspect Plant Ecol Evol Syst 3:115-127

18. Ji S, Liu EF, Zhu YX, Hu SY, Qu WC (2007) Distribution and chemical fractionation of heavy metals in recent sediments from Lake Taihu, China. Hydrobiologia 581:141-150

19. Yang H, Shen Z, Zhu S, Wang W (2008) Heavy metals in wetland plants and soil of Lake Taihu, China. Environ Toxicol Chem 27:38-42

20. Hassan S, Schmieder K, Bocker R (2010) Spatial patterns of submerged macrophytes and heavy metals in the hypertrophic, contaminated, shallow reservoir Lake Qattieneh/Syria. Limnologica 40:54-60

21. Chatterjee $S$, Chetia M, Singh L, Chattopadhyay B, Datta S, Mukhopadhyay SK (2011) A study on the phytoaccumulation of waste elements in wetland plants of a Ramsar site in India. Environ Monit Assess 178:361-371

22. Fawzy MA, Badr NE, Khatib A, Kassem AA (2012) Heavy metal biomonitoring and phytoremediation potentialities of aquatic macrophytes in River Nile. Environ Monit Assess 184:1753-1771

23. Galal TM, Farahat EA (2015) The invasive macrophyte Pistia stratiotes as a bioindicator for water pollution in Lake Mariut, Egypt. Environ Monit Assess 187:701

24. Esmaeilzadeh M, Karbassi A, Moattar F (2016) Heavy metals in sediments and their bioaccumulation in Phragmites australis in the Anzali wetland of Iran. Chin J Oceanol Limnol 34:810-820

25. Meitei MD, Prasad MNV (2016) Bioaccumulation of nutrients and metals in sediment, water, and phoomdi from Loktak Lake (Ramsar site), northeast India: phytoremediation options and risk assessment. Environ Monit Assess 188:329

26. Bonanno G, Cirelli GL (2017) Comparative analysis of element concentrations and translocation in three wetland congener plants Typha domingensis, Typha latifolia and Typha angustifolia. Ecotoxicol Environ Saf 143:92-101

27. Vivek R, Subodh KM (2018) Metal accumulation strategies of emergent plants in natural wetland ecosystems contaminated with coke oven effluent. Bull Environ Contam Toxicol 101:55-60

28. Bai J, Cui B, Chen B, Zhang K, Deng W, Gao H, Xiao R (2011) Spatial distribution and ecological risk assessment of heavy metals in surface sediments from a typical plateau lake wetland, China. Ecol Model 222:301-306

29. Liu H, Li W (2011) Dissolved trace elements and heavy metals from the shallow lakes in the middle and lower reaches of the Yangtze River region, China. Environ Earth Sci 62:1503-1511

30. Zeng H, Wu J (2013) Heavy metal pollution of lakes along the mid-lower reaches of the Yangtze River in China intensity, sources and spatial patterns. Int J Environ Res Public Health 10:793-807

31. Zhang L, Shao H (2013) Heavy metal pollution in sediments from aquatic ecosystems in China. Clean: Soil, Air, Water 41:878-882

32. El-Gammal M, Shata M, Hamouda A, El-Gharabawy S (2013) Assessment of heavy metals concentration in Mediterranean surficial sediments in front of Damietta promontory. Egypt J Environ Sci 42(3):417-432

33. Yang J, Chen L, Liu LZ, Shi WL, Meng XZ (2014) Comprehensive risk assessment of heavy metals in lake sediment from public parks in Shanghai. Ecotoxicol Environ Saf 102:129-135 
34. Chen Z, Salem A, Xu Z, Zhang W (2010) Ecological implications of heavy metal concentrations in the sediments of Burullus Lagoon of Nile Delta, Egypt. Estuar Coast Shelf Sci 86:491-498

35. Jarup L (2003) Hazards of heavy metal contamination. Br Med Bull 68:167-182

36. Johri N, Jacquillet G, Unwin R (2010) Heavy metal poisoning the effects of cadmium on the kidney. Biometals 23:783-792

37. Govindasamy C, Arulpriya M, Ruban P, Francisca JL, Ilayaraja A (2011) Concentration of heavy metals in seagrasses tissue of the Palk Strait, Bay of Bengal. Int J Environ Sci 2(1):145-153

38. ATSDR (2012) Agency for toxic substances and disease registry. Toxicological profile for Cadmium, US Department of Health and Human Services, Public Health Service, 205-93-0606

39. ATSDR (2007) Agency for toxic substances and disease registry. Toxicological Profile for Lead, US Department of Health and Human Services, Public Health Service, Delhi, 205-93-0606

40. Jumbe AS, Nandini N (2009) Impact assessment of heavy metals pollution of Vartur Lake. J Appl Nat Sci 1:53-61

41. Jibril SA, Hassan SA, Ishak CF, Wahab PEM (2017) Cadmium toxicity affects phytochemicals and nutrient elements composition of lettuce (Lactuca sativa L.). Adv Agric 2017:1-7

42. Ali H, Khan E, Sajad MA (2013) Phytoremediation of heavy metals-concepts and applications. Chemosphere 91:869-881

43. Wang J, Liu R, Ling M, Yu P, Tang A (2010) Heavy metals contamination and its sources in the Luoyuan Bay. Procedia Environ Sci 2:1188-1192

44. Shanker AK, Cervantes C, Tavera HL, Avudainayagam S (2005) Chromium toxicity in plants. Environ Int 31:739-753

45. Emmanuel E, Sombo T, Ugwanyi J (2018) Assessment of heavy metals concentration in shore sediments from the bank of River Benue, North-Central Nigeria. J Geosci Environ Prot 6:35-48

46. Chen C, Huang D, Liu J (2009) Functions and toxicity of nickel in plants: recent advances and future prospects. Clean 37(4-5):304-313

47. Sharma P, Dubey RS (2005) Lead toxicity in plants. Braz J Plant Physiol 17(1):35-52

48. Abbasi SA, Abbasi N, Soni R (1998) Heavy metals in the environment. Mital Publication, New Delhi

49. Meitei MD, Prasad MNV (2014) Adsorption of Cu, Mn and $\mathrm{Zn}$ by Spirodela polyrhiza equilibrium, kinetic and thermodynamic studies. Ecol Eng 71:308-317

50. Malik NJ, Chamon AS, Mondal MD, Elahi SF, Faiz SMA (2011) Effects of different levels of zinc on growth and yield of red amaranth and rice. J Bangladesh Assoc Young Res 1:79-91

51. Ackova DG (2018) Heavy metals and their general toxicity on plants. Plant Sci Today 5(1):14-18

52. Muhammad A, Shafaqat A, Muhammad R, Muhammad I, Farhat A, Mujahid F, Muhammad ZR, Muhammad KI, Saima $A B$ (2015) The effect of excess copper on growth and physiology of important food crops: a review. Environ Sci Pollut Res 22:8148-8162

53. Bassi N, Kumar MD, Sharma A, Pardha-Saradhi P (2014) Status of wetlands in India: a review of extent, ecosystem benefits, threats and management strategies. J Hydrol Reg Stud 2:1-19

54. Government of Karnataka (1990) Karnataka state gazetteer. Lotus Printers, Bangalore, pp. 970, 16: 215

55. Mahapatra DM, Chanakya HN, Ramachandra TV (2011) Role of macrophytes in a sewage fed urban Lake. IIOABJ 2(8):1-9

56. Ramachandra TV, Durga MM, Vinay S, Sincy V, Asulabha KS, Sudarshan PB, Bharath HA (2017) Bellandur and Varthur lakes rejuvenation blueprint. ENVIS Technical Report 116, Environmental Information System, CES, Indian Institute of Science, Bangalore 560012

57. Cook CDK (1996) Aquatic and wetland plants of India. Oxford University Press, New Delhi
58. APHA (1995) Standard methods for the examination of water and waste water, 19th edn. American Public Health Association, Washington

59. Zhang M, Cui L, Sheng L, Wang $Y$ (2009) Distribution and enrichment of heavy metals among sediments, water body and plants in Hengshuihu Wetland of Northern China. Ecol Eng 35:563-569

60. Zhang W, Cai Y, Tu C, Ma LQ (2002) Arsenic speciation and distribution in an arsenic hyper accumulating plant. Sci Total Environ 300:167-177

61. Deng $\mathrm{H}$, Ye ZH, Wong MH (2004) Accumulation of lead, zinc, copper and cadmium by 12 wetland plant species thriving in metal-contaminated sites in China. Environ Pollut 132(1):29-40

62. MacDonald DD, Ingersoll CG, Berger TA (2000) Development and evaluation of consensus-based sediment quality guidelines for freshwater ecosystems. Arch Environ Contam Toxicol 39:20-31

63. Maiti SK (2003) Handbook of methods in environmental studiesvol 2: air, noise, soil and overburden analysis. ABD Publishers, Jaipur

64. Jaan-Mati P, Kaire T (1999) C/N ratio and fossil pigments in sediments of some Estonian lakes: an evidence of human impact and Holocene environmental change. Environ Monit Assess 64:549-567

65. Hassan KM, Swinehart JB, Spalding RF (1997) Evidence for Holocene environmental change from $\mathrm{C} / \mathrm{N}$ ratio, and $\delta 13 \mathrm{C}$ and $\delta 15 \mathrm{~N}$ values in Swan Lake sediments, Western Sand Hills, Nabraska. J Paleolimnol 18:121-130

66. Mahapatra DM, Chanakya HN, Ramachandra TV (2001) C: N ratio of sediments in a sewage fed urban Lake. Int J Geol 3(5):86-92

67. Meyers PA (1994) Preservation of elemental and isotopic source identification of sedimentary organic matter. Chem Geol 114:289-302

68. Guilizzoni PA, Marchetto A, Lami G, Cameron P, Appleby NL, Schnell OA, Schnell CA, Belis A, Giorgis A, Guzzi L (1996) The environmental history of a mountain lake (Lago Paione Superiore, Central Alps, Italy) for the last c. 100 years: a multidisciplinary, paleolimnological study. J Paleolimnol 15:245-264

69. Wilson MJ, Bell N (1996) Acid deposition and heavy metal mobilization. Appl Geochem 11:133-137

70. Prasad MNV (1995) Cadmium toxicity and tolerance in vascular plants. Environ Exp Bot 35:525-545

71. Li M, Zhang LJ, Tao L, Li W (2008) Ecophysiological responses of Jussiaea rapens to cadmium exposure. Aquat Bot 88:347-352

72. Prasad MNV (2004) Heavy metal stress in plants: from biomolecules to ecosystems, 2nd edn. Springer, Berlin

73. Irfana S, Farooq AL, Mehrajuddin N (2018) Preliminary assessment of heavy metals in water, sediment and macrophyte (Lemna minor) collected from Anchar Lake, Kashmir, India. Appl Water Sci 8:80

74. Rashid SA, Ganai JA, Masoodi A (2014) Major and trace element geochemistry of lake sediments, India: implications for weathering and climate control. Arab J Geosci 8(8):1-8

75. Singh J, Upadhyay SK (2012) Heavy metals assessment in sediment of Ramgarh Lake, UP, India. J Ecophysiol Occup Health 12:13-19

76. Suresh G, Sutharsan P, Ramasamy V, Venkatachalapthy R (2012) Assessment of spatial distribution and potential ecological risk of the heavy metals in relation to granulometric contents of Veeranam Lake sediments, India. Ecotoxicol Environ Saf 84:117-124

77. Shirisha K, Sahrawat KL, Devi P, Wani SP (2016) Heavy metal concentrations in sediments collected from ICRISAT Lake, Patancheru, India. Commun Soil Sci Plan 47(3):348-355

78. Gopal V, Hema A, Jayaprakash M (2017) Assessment of trace metals in Yercaud Lake sediments, southern India. Environ Earth Sci 76:63 
79. Swarnalatha K, Letha J, Ayoob S (2014) Effect of seasonal variations on the surface sediment heavy metal enrichment of a lake in South India. Environ Monit Assess 186:4153-4168

80. Rai PK (2010) Seasonal monitoring of heavy metals and physicochemical characteristics in a lentic ecosystem of subtropical industrial region, India. Environ Monit Assess 165:407-433

81. Kumar B, Shah R, Mukherjee D (2011) Geochemical distribution of heavy metals in sediments from sewage fed fish ponds from Kolkata Wetlands, India. Chem Spec Bioavailab 23(1):24-32

82. Balamurugan $P$, Vasudevan $S$, Selvaganapathi R, Nishikanth CV (2014) Spatial distribution of grain size characteristics and its role in interpreting the sedimentary depositional environment, Kodaikanal Lake, Tamil Nadu, India. J Earth Sci Clim Change 5:217

83. Pal D, Maiti SK (2018) Seasonal variation of heavy metals in water, sediment, and highly consumed cultured fish (Labeo rohita and Labeo bata) and potential health risk assessment in aquaculture pond of the coal city, Dhanbad (India). Environ Sci Pollut Res 25:12464-12480

84. Rai PK (2009) Heavy metals in water, sediments and wetland plants in an aquatic ecosystem of tropical industrial region, India. Environ Monit Assess 158:433-457

85. Singh N, Kaur M, Katnoria JK (2017) Analysis on bioaccumulation of metals in aquatic environment of Beas River Basin: a case study from Kanjli wetland. GeoHealth 1:93-105

86. Pandey VC (2016) Phytoremediation efficiency of Eichhornia crassipes in fly ash pond. Int J Phytoremediat 18:450-452

87. Zaidi J, Khan AH, Pal A (2017) Some aquatic macrophytes and their metal accumulation potentiality. J Ecophysiol Occup Health 17(3\&4):93-100

88. Shingadgaon SS, Chavan BL (2019) Evaluation of bioaccumulation factor, bioconcentration factor, translocation factor and metal enrichment factor abilities of aquatic macrophyte species exposed to metal contaminated wastewater. Int J Innov Res Sci Eng Technol 8(1):329-347

89. Pandey SK, Upadhyay RK, Gupta VK, Worku K, Lamba D (2019) Phytoremediation potential of macrophytes of urban waterbodies in central India. J Health Pollut 9(24):191206
90. Jha P, Samal AC, Santra SC, Dewanji A (2016) Heavy metal accumulation potential of some wetland plants growing naturally in the city of Kolkata, India. Am J Plant Sci 7:2112-2137

91. Khankhane PJ, Sushilkumar BHS (2014) Heavy metal extracting potential of common aquatic weeds. Indian J Weed Sci 46(4):361-363

92. Singh NK, Raghubanshi AS, Upadhyay AK, Rai UN (2016) Arsenic and other heavy metal accumulation in plants and algae growing naturally in contaminated area of West Bengal, India. Ecotoxicol Environ Saf 130:224-233

93. Kumar NJl, Soni H, Kumar RN, Bhatt I (2008) Macrophytes in phytoremediation of heavy metal contaminated water and sediments in Pariyej community reserve, Gujarat, India. Turk J Fish Aquat Sci 8:193-200

94. Mazumdar K, Das S (2015) Phytoremediation of Pb, Zn, Fe, and $\mathrm{Mg}$ with 25 wetland plant species from a paper mill contaminated site in North East India. Environ Sci Pollut Res 22:701-710

95. Suthari S, Kiran BD, Prasad MNV (2017) Health risks of leafy vegetable Alternanthera philoxeroides (Alligator weed) rich in phytochemicals and minerals. Eurobiotech J 1(4):293-302

96. Khatun A, Pal S, Mukherjee AK, Samanta P, Mondal S, Kole D, Chandra P, Ghosh AR (2016) Evaluation of metal contamination and phytoremediation potential of aquatic macrophytes of East Kolkata Wetlands, India. Environ Health Toxicol 31:e2016021

97. Rana V, Maiti SK (2018) Metal accumulation strategies of emergent plants in natural wetland ecosystems contaminated with coke oven effluent. Bull Environ Contam Toxicol 101:55-60

98. Yang Y, Liang Y, Ghosh A, Song Y, Chen H, Tang M (2015) Assessment of arbuscular mycorrhizal fungi status and heavy metal accumulation characteristics of tree species in a lead-zinc mine area: potential applications for phytoremediation. Environ Sci Pollut Res 22(17):13179-13193

Publisher's Note Springer Nature remains neutral with regard to jurisdictional claims in published maps and institutional affiliations. 